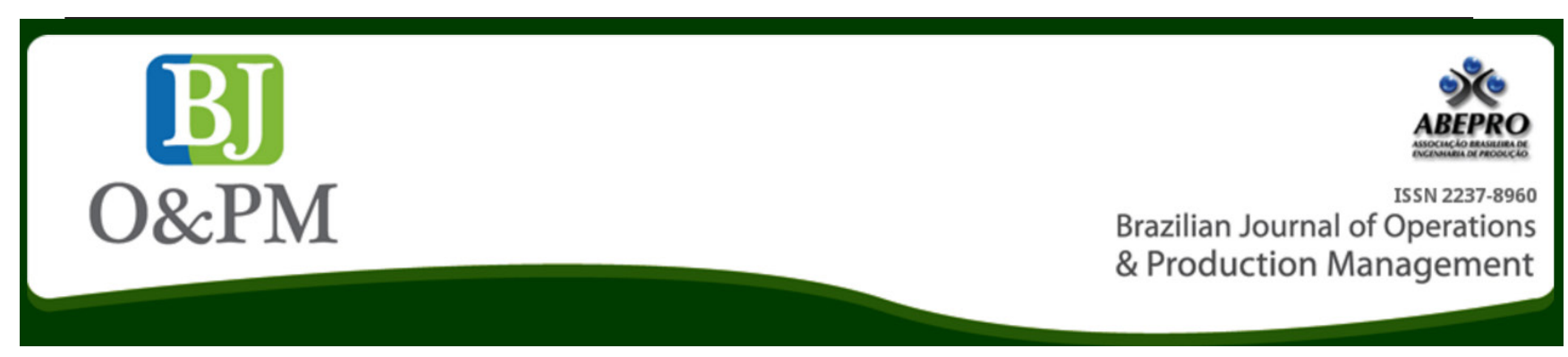

\title{
IMPACT ANALYSIS OF IT USE IN LOGISTICAL COSTS OF A BRAZILIAN BEVERAGE COMPANY
}

\author{
Fabio Aquino da Silva ; Valmir Martins Oliveira ${ }^{b}$ \\ a Fluminense Federal University (UFF) - Niterói, RJ, Brazil \\ b Universidad Mayor - Santiago, Chile
}

\begin{abstract}
Purpose - The main goal of this paper is to identify the impact that the use of Information Technology (IT) provides to the logistical costs of a company in the beverage industry. This research work proposes the theoretical framework that gives instructions for firms' for construction of indicators for assessing the costs that make up the logistics activity is also influenced by technologies used in business
\end{abstract}

Design/methodology/approach - The proposed framework covers the stages of the logistics process that has IT operations. The theoretical model is offered according to existing studies and literature resources. The approach focuses on theoretical considerations and methodological. A single case study, with the calculation of data through a questionnaire, was answered by the executive responsible for defining the operational strategy.

Findings - Formalization would enable firms to profitably handle their logistics operations, especially when returns involve a number of uncertainties such as increasing volume of returns, the unstable time, and different types/conditions of returned products. The main findings are supported by the literature review, which notes that the financial and operational indicators set using software, are important to the company's good management practices

Research limitations/implications - The theoretical considerations and methodological work as an object of future research and suggest the application of this model to different suppliers of IT solutions. The use of these attributes in other segments of the domestic industry, in order to verify their behavior and their application.

Practical implications - Companies, using the proposed reference material, can effectively understand the use of IT contribution in their logistics activities, especially in the control of operating costs

Originality/value - Some theoretical frameworks presented in the work contribute to the reasons for the use of Ti to help companies formulate their logistics programs. In this way, especially when the operation is decentralized and complex.

Keywords: Costs; IT; Logistics; Bevere Industry 


\section{INTRODUCTION}

One of globalization effects is the elimination of obstacles for international economic activities, and a significant improvement in all business activities has been noticed, largely influenced by recent technological developments, especially in transports (KRAJNC et al., 2012). Information technologies (IT), as well as other electronic resources help companies to serve their customers with quality, flexibility in delivery dates, and differentiated services provided to special customers. It is particularly remarkable when the market sector in which it operates has several distribution channels.

It has been proposed that decision makers that act as business planners are increasingly dependent on information provision in order to achieve logistical cost computing (BOKOR, 2011). It has been estimated that logistics costs undertake up to $10 \%$ of total costs of a company (ENGBLOM et al., 2012).

The purpose of this research was to discuss the impact of IT tools on management practices and control of a company's logistic costs. Moreover, we highlight the optimization of available resources analyzing the positive aspects of IT usage, provided by the interface between company management and the logistical area.

The studied operates on the beverage sector in Brazil, Europe and some South American countries. It presents logistical challenges, particularly due to its strategy of acquiring smaller companies of its segment in new markets, where it does not have branches. Therefore, the employment of IT tools in operations represents a facilitator for the logistics costs' decision making, involving the company's expansion into these new markets.

It is well known that the construction of a company's efficient growth model should be based on good planning and management of logistics costs, aiming to a better usage of resources (FERREIRA et SCHNORR, 2011). The present article analyzes the impact of IT usage on logistic operation costs, and it is composed by five sections: Introduction, Literature Review, Method, Analysis and Interpretation of Results, and Conclusion.

\section{LITERATURE REVIEW}

\subsection{Impacts of IT usage on company's logistic operations}

It has been recently proposed that the benefit of IT utilization relies on the easiness of recovering data to make decisions relating to operational safety, flow and performance, which generates customer satisfaction and eliminates uncertainties (BAHRI et al., 2016). Additionally, an important aspect that must be considered is to rationalize competing concerns, which apart from the contribution with monitoring, also plays an integrative role in data identification and reporting to Enterprise Resource Planning - ERP (ASSIS, 2016). The communication action is facilitated by conflicts' reduction, which helps to organize products' boarding and landing as well as to define the vehicle employed on the goods' transport.

The return on the company's investment in IT acquisition relies on an improved operating flow associated to a better management of logistics operational costs. Although IT technology helps on improving the company's results' management, customization of parameters should be reviewed whenever the operational strategy is changed (DE FATIMA et al., 2016; MARTIN, 2016).

It must also be considered that the company must track the regular supply of information through the use of IT technology since it occupies a key position in a complex operation. It faces geographical difficulties and meets uninterrupted demand 24 hours a day, 7 days a week (MENESES et SANNA, 2016). It has also been demonstrated that the use of IT improves information service and quality, important advantages for enterprise cost analysis. It enables the company to have full control on expenditures and, when it is well implemented, provides flexibility in logistical processes, positively influencing the company's costs. As the company operates in different markets, IT technology is required to meet the demands and expectation of service on different locations (DE NIE et al., 2016; MACIEL, 2015).

The required infrastructure for IT usage can be defined as a set of technological resources to support the implementation of current or future business. The company maintains its infrastructure directed to the provided services, and organizes its server in order to suit the client versus product demand (MENDONÇA et al., 2013). Table 1 summarizes the main impacts that may affect the operation with the use of IT within its structure.

Table 1. Summary of expected IT use impacts in the logistics operation

\begin{tabular}{|c|c|c|}
\hline Atributes & Impacts & References \\
\hline $\begin{array}{c}\text { Competing concerns } \\
\text { rationalization }\end{array}$ & Monitoring & $\begin{array}{c}\text { Bahri } \text { et al. (2016); } \\
\text { Assis (2016) }\end{array}$ \\
\hline $\begin{array}{c}\text { Return of Investment } \\
\text { on IT }\end{array}$ & Better operational flow & $\begin{array}{c}\text { De Fátima } \text { et al. } \\
\text { (2016); Martins } \\
\text { (2016) }\end{array}$ \\
\hline Regularity & Service continuity & $\begin{array}{c}\text { Meneses } \text { et Sanna } \\
\text { (2016) }\end{array}$ \\
\hline $\begin{array}{c}\text { Service and } \\
\text { Information Quality }\end{array}$ & Expenditure control & $\begin{array}{c}\text { De Fátima } \text { et al. } \\
\text { (2016) }\end{array}$ \\
\hline Infrastexpectedructure & $\begin{array}{c}\text { Client vs product } \\
\text { demand organization }\end{array}$ & $\begin{array}{c}\text { Mendonça } \text { et } \text { (2013) } \\
\text { (2013) }\end{array}$ \\
\hline
\end{tabular}

Source: The author(s) own

\subsection{ITs that contribute to the reduction of transaction costs}

The cost of a transactional activity is an essential indicator reflecting the cost of the whole system use (VARGAS, 2016). 
Reducing transactions costs can be aided by Electronic Data Interchange - EDI technology, which provides flexibility in electronic data interchange (BRUM, 2016). Thus, an immediate impact on reducing costs within transactions is observed in the management of requests from its logistics upstream suppliers responsible for the entry of inputs into the factories. This may eliminate intermediate steps in the administrative process, such as the processing of applications. Moreover, suppliers on downstream production chain may benefit from the electronic money transfer, facilitating orders' monitoring and greater control of revenue. That logistics activities always need more investment in technology in order to achieve electronic data exchange, which provides resource sharing and consolidation of flows, i.e., the rationalization of logistics costs (MASSON et PETIOT, 2012).

Transportation Management System - TMS is an example that characterizes the integration of IT use in transportation along with other activities that improves the logistics of the company (SILVA, 2016). With real time control of operations, the company is able to continuously update management information, which provides better management of the freight cost. TMS has the ability to help the company to build and run the freight auction, which has direct impact on transport costs, what represent much of logistical costs (DE OLIVEIRA et FERRAZ, 2016). Moreover, tools' integration enables the entire operation process and logistical management to occur within a single database, ensuring speed and accuracy of information on the cost of transport and products delivery. Therefore, the adequate management of transport is directly reflected on the company's logistical costs.

Cargo handling should not count for logistics costs, especially when it occurs within the warehouse where product shipping, handling and storage costs are observed. Warehouse Management System - WMS technology is another IT tool used to manage warehouses through bar codes and mobile devices. WMS monitors products and reports their position when they are shipped, avoiding unnecessary handling (ROSA et al., 2015; ATIEH et al., 2016).

In order to achieve good management, it is necessary to syncronize all existing ITs within a company's structure. This will also improve the relationship with customers and suppliers. It has been stated that a company that uses the Enterprise Resource Planning -ERP in its operations can provide faster response time to customer's demands, performing remote tests which also contribute to the reduction of company's operating costs, (VAN DER WESHUIZEN, 2016; LOPEZ et al., 2016).

Another IT tool, the Event Data Recorder - EDR, contributes to control logistical operations by recording the performance of cargo transport vehicles. Informally it can be compared to the existing black box on airplanes. The module is installed in the vehicle and controls data through sensors such as speed, letups, operating time and others that can be customized. Therefore, the company has access to data needed to construct indicators directly impacting logistical costs (DE OLIVEIRA et FERRAZ, 2016).

Table 2 presents a summary of Tls' impact on logistics costs observed throughout the company.

Table 2. Summary of ITs and their contribution to logistic costs

\begin{tabular}{|c|c|c|}
\hline Used ITs & $\begin{array}{c}\text { Impact on logistic } \\
\text { operations }\end{array}$ & References \\
\hline EDI & $\begin{array}{c}\text { Reduction of } \\
\text { Transactional Costs }\end{array}$ & $\begin{array}{c}\text { Vargas (2016); Brum (2016); } \\
\text { Masson and Petiot (2012) }\end{array}$ \\
\hline TMS & $\begin{array}{c}\text { Reduction of } \\
\text { Transportation Costs }\end{array}$ & $\begin{array}{c}\text { Silva (2016); De Oliveira e Ferraz } \\
\text { (2016); }\end{array}$ \\
\hline WMS & $\begin{array}{c}\text { Reduction of } \\
\text { Warehouse Costs }\end{array}$ & $\begin{array}{c}\text { Atieh et al. (2016); Rosa et al } \\
\text { (2015); }\end{array}$ \\
\hline ERP & $\begin{array}{c}\text { Reduction of } \\
\text { Response Time }\end{array}$ & $\begin{array}{c}\text { Van Der Weshuizen, (2016); Lopez- } \\
\text { Gordo et al. (2016) }\end{array}$ \\
\hline EDR & $\begin{array}{c}\text { Control of Vehicles' } \\
\text { Performance Data }\end{array}$ & De Oliveira e Ferraz (2016) \\
\hline \multicolumn{2}{|c|}{ Source: The author(s) own } \\
\hline
\end{tabular}

A company that has its cargo handling logistics concentrated on trucks needs to use the ITs summarized in Table 2 to perform its freight auction when it evaluates suppliers through multiple and complex criteria. The use of IT influences costs and it can be seen in the selection efficiency of suppliers through the freight auction because they facilitate the selection of the most suitable supplier to carry out a transport operation.

\subsection{Logistics costs}

To Engblom et al. (2012), logistics consist of six cost elements: management, warehousing, inventory management, shipping, packing and indirect costs. These costs influence activities such as planning, implementation and control of all materials and services that the company uses or provides.

According to Somuyiwa (2010), there is nothing new about logistical components. What can be innovated is the management of resources that are employed in operations. The main focus is on reducing or eliminating activities that do not directly add value to the product, such as to inspect incoming and outgoing information in the system.

\subsection{Benefits on using ITs in logistics operations}

The correct information will be significant only if the company can interconnect data to support the decision making up. The continuous flow of information relevant to operations occurs through the use of an IT architecture interfacing the company and its logistical operators. For Stevens et Johnson (2016), reducing the amount the company 
spends on the production of management information will only be successful if there is an integration between internal customers, and when TIs' generation support is mandatory to logistical operations with focus on cost management.

Use of technology avoids repeated delays in the transportation path motivated by traffic problems, malfunction of the vehicle, or even climate changes, which can generate greater difficulty in passing on all the information to the management decision. For Peng et al., (2016) this should be observed to prevent a greater operation difficulty than expected affecting the company's performance.

D 'Alva (2016) argues that the correct use of IT provides benefits as estimated time arrival forecast of the truck to its destination. This forecast is composed of variables that would hardly be controlled without the use of these technologies. With this estimation the company and the driver can increase productivity by reducing vehicle downtime in the factory awaiting to load, and also reducing the area needed for maneuvering vehicles in the inner courtyard.

For Morais et Tavares (2011), it is not recognized the benefit provided by the use of IT reflected on the possibility of adding value to the organization logistical process. IT technology presents performance indicators providing the identification of opportunities, which should be adjusted daily to improve their management. Indicators most commonly used by the company through ITs are of financial and operational nature. The former indicator - financial presents the fixed cost of logistics, warehousing cost, storage cost and the cost of its own fleet maintenance compared to outsourced fleet. Operational indicators comprise the fleet occupation and the volume transported by the fleet compared to the volume transported by the outsourced fleet.

\section{METHODOLOGY}

Based on Gil (2010), this research has qualitative and investigative characteristics, being composed of bibliographic steps and case study. The qualitative bibliography is based on authors, sites and other elements that provide the resolution of the proposed theme characterizing it for the preparation of results. The case study presents an investigative character to explore and describe events. Flick (2012) argues that, based on the characteristics of the phenomenon, the focus of the study should look at the data collection process and at strategies for their analysis.

According to Yin (2005, p.20), a case study is used as a research strategy in many situations to contribute to our knowledge of phenomena - individual, social, organizational, political, groupal, and other related phenomena. Thus, case studies usually integrate common search strategies in administration processes.
The use of a single case study is justified by the experience and institutional representation of the interviewed person, yet according to Yin $(2005$, p.63). Thus, despite the large amount of information produced, the company seeks to maintain a uniformity for operational decisions that happen centrally within its business environment.

Bibliometrics were based on Costa (2010), and focused on journals' articles of Scopus and Scielo search bases. For entry criteria in the system, keywords were composed by crossing. To restrict and meet our objective, we used as filters the publication dates from 2013 to 2016; manual verification of matters relating to the study purpose by research areas; Portuguese and English languages; and articles where words appeared nowhere but in summaries. Immediate results summed up to 358 articles, which arranged in descending order allowed to select 39 works published on journals of higher Journal Citation Reports - JCR. Those items served to compose the "starting core" to kick off the survey.

For the interview we used as research instrument the data collection technique made up by a questionnaire where questions were divided into two blocks: impact on logistics and IT benefits in logistics. On the first block, closed questions were presented and answers were rated on a Likert scale - 1 = very low; 2 = low; 3 = average; 4 = high; and $5=$ very high. On the second block, questions were aimed at classifying, under the company's perspective, the benefits of some aspects of the IT use in its operations.

The survey was conducted from March to April 2016, when we interviewed a senior manager with 16 years of management experience. For the last two years he has been ahead his company's logistics operation. The respondent has a degree background in management and post graduation in logistics expertise, and is responsible for the company's logistics strategy.

This case study was conducted in a drink industry company with open capital operating in 18 countries, with some units in Brazil providing beverages throughout the national territory. The company uses ITs since 2010, which is the subject of this study. Its focus is on primary operations, defined by the movement of feedstocks to furnish plants for their productive activities.

\section{ANALYSIS AND INTERPRETATION OF RESULTS}

The respondent informed that ITs are routinely applied in much of the logistics operation providing $20 \%$ reduction on operating costs. Their use have five advantageous aspects presented in Table 3, assessed by the respondent where he assigned scores from 1 to 5 to value how these issues have impacted the performance of the activities within the logistics processes. The aspects were scored as follows: 
Table 3. Contribution to cost reduction through the use of IT in logistics

\begin{tabular}{|c|c|c|c|c|c|}
\hline \multirow{2}{*}{$\begin{array}{c}\text { Impact on Logistic } \\
\text { Operation }\end{array}$} & \multicolumn{5}{|c|}{ Rating } \\
\cline { 2 - 6 } & $\mathbf{1}$ & $\mathbf{2}$ & $\mathbf{3}$ & $\mathbf{4}$ & $\mathbf{5}$ \\
\hline $\begin{array}{c}\text { Reduction on Transactional } \\
\text { Cost }\end{array}$ & & $\mathrm{X}$ & & & \\
\hline $\begin{array}{c}\text { Reduction on } \\
\text { Transportation Cost }\end{array}$ & & $\mathrm{X}$ & & \\
\hline $\begin{array}{c}\text { Reduction on Warehouse } \\
\text { Cost }\end{array}$ & & & $\mathrm{X}$ & \\
\hline $\begin{array}{c}\text { Reduction on Response } \\
\text { Time }\end{array}$ & & & & $\mathrm{X}$ \\
\hline $\begin{array}{c}\text { Reduction on Operational } \\
\text { Shutdown }\end{array}$ & & & $\mathrm{X}$ & \\
\hline $\begin{array}{c}\text { Control of Vehicle } \\
\text { Performance Data }\end{array}$ & \multicolumn{2}{|c|}{$\mathrm{X}$} & & \\
\hline \multicolumn{2}{|c|}{ Source: The author(s) own } & & \\
\hline
\end{tabular}

The Reduction in Transactional Cost aspect was rated with the least contribution of impact on the logistical operational costs. For the interviewee, this aspect has a direct influence of the Electronic Data Interchange - EDI action. It allows the company to operate at its lowest transactional cost level.

The Reduction on Transportation Cost aspect occurs via TMS and is classified as a median contribution since IT facilitates decisions' prediction. Nevertheless the company faces non-routine situations such as accidents and vehicles' break, cropping out lack of foresight that makes it difficult to maintain a minimum cost for the transport operation. Another operation issue is the fact that part of the fleet is outsourced and does not use the software preventing strategic alignment.

The Reduction on Warehouse Cost aspect received a score of 4 ranking a high impact on logistical total cost of the company. The use of WMS simultaneously with other features provides a faster identification of possible errors, thus giving more flexibility in corrective action, which is important for the integration of logistics in a complex system.

The Reduction on Response Time of the company to its customer ranks with the highest score in the reduction of operating costs. It shows the importance the company gives to provide faster responses and control the operation through IT. The top mark assigned by the respondent shows the company observes the impact the use of technology weighs on its costs.

The Reduction on Operational Shutdown aspect obtained a score of 4 , which shows that the company aiming decision making trusts on data generated by the system for scenarios' construction. The company can achieve maintaining the scheduled operation to reach the goal established with preventive maintenance avoiding the high costs of a corrective maintenance.

The Controls Vehicle Performance Data aspect received an average assessment for reasons such as: a) a part of the trucks is outsourced then the responsibility to monitor productivity is up to the contractor; b) company's own fleet uses much of the information for the item security, which is done by an IT supplier, so does not need constant updating through IT.

The second block of questions shows the benefits the company gains with some aspects of IT use providing reduction in total costs of the company's logistics operation. Regarding the main benefits observed, the respondent indicated 'yes' to the following: Competing Concerns Rationalization, Return of Investment on IT, Regularity on Information Flow, Service and Information Quality, and Infrastructure. Table 4 shows the questionnaire results.

Table 4. Impacts from IT use

\begin{tabular}{|c|c|c|c|c|c|}
\hline \multirow{2}{*}{ Impacts Influenced by IT } & \multicolumn{5}{|c|}{ Rating } \\
\hline & 1 & 2 & 3 & 4 & 5 \\
\hline $\begin{array}{c}\text { Competing Concerns } \\
\text { Rationalization } \\
\end{array}$ & & & & $x$ & \\
\hline Return of Investment on IT & & & $x$ & & \\
\hline $\begin{array}{c}\text { Regularity on Information } \\
\text { Flow }\end{array}$ & & & $\mathrm{X}$ & & \\
\hline $\begin{array}{c}\text { Service and Information } \\
\text { Quality }\end{array}$ & & & & $x$ & \\
\hline Infrastructure & & & & $x$ & \\
\hline
\end{tabular}

The Competing Concerns Rationalization aspect was evaluated with grade 4 , which shows its high contribution to the reduction of logistical operational costs. This is because sometimes the service provider does not meet the provisions at service level agreement, affecting the total cost of the entire company.

Both Return of Investment on IT and Regularity on Information Flow aspects were classified with an average impact on the company's satisfaction framework, regarding the use of technology. The evaluation of investment return is a decision attained to a scope at the level of the company's strategies, a process that needs to be matured and requires a certain time to set. The regular supply of information provides a direct impact on the operation of the company. Since its implementation, the concern is to maintain system's stability for operations' smooth running.

The Service and Information Quality aspect was rated with high impact. The respondent points out that this aspect provides the control of the company's financial performance leading to a better use of company's resources. The Infrastructure aspect received 4 representing a high impact on the company's logistics operation. The respondent argues that it is important for the company to have its own database because using a dedicated database eases, organizes and controls the relationship between its customers' demands and the products offered by the company.

\section{CONCLUSION}

The use of IT in logistics operation contributes to the reduction of logistics costs, which can be seen in process 
Brazilian Journal of Operations \& Production Management

Volume 14, Número 1, 2017, pp. 20-26

DOI: 10.14488/BJOPM.2017.v14.n1.a3

automation. The company gets faster decision making and greater amount of information to support the management action. These aspects are represented by the scores they received in assessment. The company recognizes the importance of using ITs logistics, as well as the integration this technology provides improving the level of services to the client, although it has difficulty to measure the impact of these technologies' use.

The main impacts are checked in financial costs and operating costs, freight auction, which in addition to setting the provider, emerges as the indicator that is dependent in its entirety the application of the financial features of the Tls. Operating costs, the main impact is the volume capacity carried by the company's operation, so it takes advantage of new business opportunities, which will result in increased profitability.

Ts have as its main feature being a facilitator management actors, such as customers and suppliers and thus generate greater satisfaction to their logistics providers, providing the company to operate with reduced costs. For the operation of this systematic, it is necessary that the organization note the positive impact provided by the software, preventing incorrect assessments.

The evaluation of an IT should be performed so that the cost schedule is not undersized or overestimated, preventing the strategic level the company has based on erroneous data, compromising the performance of IT and business. The company led the implementation of IT so well suited to business needs, their use is continuous and is increasing the number of modules used, which shows greater control of the logistics process.

This study examined how the complex logistics operation of a beverage company has its operating costs reduced by the use of technology, which gives the company even adjust its strategy, quickly and accurately, with a focus on operating results. Thus, the analysis developed with the primary information obtained from the Brazilian beverage company, concludes that the structure of the transaction has favorable conditions for the application of IT in the logistics process, and search, optimization of the steps that make up this process, fulfilling satisfactorily as expected in the planning of activities that enabled its implementation.

Considering the scope of its application, the results also contribute to comparative analysis with various economic sectors, especially for the industrial sector on the beverage. Thus, the company has specific variables to deal with the high degree of complexity of road transport by truck, which provides greater flexibility in making management decisions with more reliable data, basing correct and available information in time skilful.

\section{REFERENCES}

Assis, W. C. de (2016). Governança de IT na administração Pública Federal: aprimorando a governança de IT no setor público brasileiro.

Atieh, A. M.; Kaylani, H.; Al-abdallat, Y.; Qaderi, A.; Ghoul, L.; Jaradat, L.; Hdairis, I. (2016). Performance Improvement of Inventory Management System Processes by an Automated Warehouse Management System.Procedia CIRP, 41, 568-572

Bahri, L.; Pasternak, W. D.; Bini, E.M. (2016). Sistema de Gerenciamento para Indústria Gráfica.

Bokor, Z. (2011). Performance-based logistics costing. 3rd IEEE International Symposium on Logistics and Industrial Informatics (LINDI), Budapest, Hungary.

Brum, P. (2016). Sistemas ERP na gestão da cadeia de suprimentos. Revista Organização Sistêmica 7.4: 79-94.

Costa, A. (2010). Boas práticas logísticas potenciam competitividade. Revista Portugal Global. Porto: AICEP Global, n.33,

D’alva, D. V. C. (2016). Otimização da Operação de Picking em Armazéns.

Andrioli, R. F.; Diehl, C. A.; Hansen, P. B. (2015). Proposta de modelo flexível para apoio à decisão de externalização: uma aplicação em logística de transporte-proposal for a flexible model for decision support of outsourcing: an Application in Transportation Logistics. GESTÃO. Org-Revista Eletrônica de Gestão Organizacional, v. 13, n. 2.

De Oliveira, L. P.; Ferraz, A. A. (2016). Integracao de Ferramentas de Telemetria e Sistemas de TMS para Gestao Operacional do Transporte Rodoviario de Cargas (TRC). Ingeniería de Transporte, v. 18, n. 2.

Engblom, J.; Solakivi, T.; Töyli, J.; Ojala, L. (2012) .Multiplemethod analysis of logistics costs. International Journal of Production Economics, v. 137, p 29-35.

Ferreira, F. B.; Schnorr, C. (2011). Práticas de gestão de custos logísticos: um estudo de caso em empresa gaúcha do setor alimentício. In: CONGRESSO BRASILEIRO DE CUSTOS, 18, 2011, Rio de Janeiro. Anais... São Leopoldo: ABC.

Flick, U. (2012). Introdução a metodologia de pesquisa. Porto Alegre: Penso.

Gil, A. C. (2010). Como elaborar projetos de pesquisa. 5. ed. São Paulo: Atlas.

Krajnc, J.; Logožar, K.; Korošec, B. (2012). Activitybased management of logistic costs in a manufacturing company: a case of increased visibility of logistics costs in a Slovenian paper manufacturing company. PROMETTraffic\&Transportation, v. 24, n. 1, p. 15-24. 
Lopez-Gordo, M.A.; Padilla, P.; Pelayo Valle, F. (2016). A proposal for bio-synchronized transmission of EEG/ERP data. EURASIP Journal on Wireless Communications and Networking.

Yin, R. K. (2005). Estudo de caso: planejamento e métodos. Porto Alegre: Bookman.

Maciel, E. de A. (2015). Relação das capacidades de TI com a qualidade da informação e com a qualidade do serviço de informação: uma análise no contexto de negócios digitais.

Martins, Á. L. M. (2016). Papel da informatização na pequena e média empresa brasileira: investimentos em TI, percepção da gestão e impacto nos resultados. Tese de Doutorado.

Masson, S.; Petiot, R. (2012). Attractivité territoriale, infrastructures logistiques et développement durable. Les Cahiers Scientifiques Du Transport, (61), 63-90.

Mendonça, C. M. C. de; Guerra, L. C. B.; Souza Neto, M. V. de; Araújo, A. G. de. (2013). Governança de tecnologia da informação: um estudo do processo decisório em organizações públicas e privadas.Rev. Adm. Pública [online]. vol.47, n.2.

Meneses, A. S. de; Sanna, M. C. (2016). Structure of knowledge about nursing administration in brazilian graduate programs. Texto \& Contexto-Enfermagem, v. 25, n. 1.

Morais, K. M. N.; Tavares, E. (2011). Use of information technology in supply chain management in São Luís do Maranhão and opportunities to the development of local suppliers. Interações, Campo Grande, v. 12, n. 2, p. 175- 191.

Peng, J.; Quan, J.; Zhang, G.; Dubinsky, A. J. (2016). Mediation effect of business process and supply chain management capabilities on the impact of IT on firm performance: Evidence from Chinese firms. International Journal of Information Management, 36(1), 89-96.

Rosa, C. R. M.; Steiner, M. T. A.; Colmenero, J. C. (2015). The use of analytic hierarchy process for the structural and operational definition of distribution centers: an application to a food company. Gestão \& Produção, v. 22, n. 4, p. 935950.

Silva, F A da (2016). A avaliação do transportation management system (tms) nas operações logísticas de uma indústria brasileira de bebidas.

Somuyiwa, A. O. (2010). Analysis of logistics cost in the Supply Chain Management of manufacturing companies in Southwestern Nigeria (2002-2006) Unpublished Ph. D Thesis. Olabisi Onabanjo University, Ago-Iwoye.

Stevens, G.; Johnson, M. (2016). Integrando a Cadeia de Abastecimento... 25 anos depois. International Journal of Physical Distribution \& Logistics Management, v. 46, n. 1.
Vargas, L. C. de M. (2016). Economia Institucional: uma análise sobre os custos de transação no Brasil.

Van Der Weshuizen, J. P.; West, M. (2016). Manutenção E Processo de Logística de negócios Cross-Funcional Integração: lições de um óleo Grande e Companhia de Gás. Journal of Applied Business Research, v 32, n.2, p. 401. 